\title{
The cytoskeletal proteins in the contractile tissues of the testis and its excurrent ducts of the passerine bird, Masked Weaver (Ploceus velatus)
}

\author{
P. C. Ozegbe ${ }^{1}$, T. A. Aire ${ }^{1,2 \dagger}$ and M. Deokar ${ }^{2}$ \\ ${ }^{1}$ Department of Veterinary Anatomy \& Physiology, Faculty of Veterinary Science, University of Pretoria, \\ Onderstepoort 0110, South Africa; ${ }^{2}$ Anatomy, Physiology \& Pharmacology Academic Program, School of \\ Veterinary Medicine, St. George's University, True Blue, St. George's, Grenada, West Indies.
}

Running title: immunohistochemistry - cytoskeleton --- male genital organs ---- Weaver bird

\begin{abstract}
Acknowledgement
The authors wish to acknowledge the Postdoctoral Fellowship awarded to PCO, the funds as well as facilities provided by the University of Pretoria, and the facilities provided by the St. George's University, where the work was completed.
\end{abstract}

\section{Corresponding author}

Professor Tom A. Aire, Anatomy, Physiology \& Pharmacology Academic Program, School of Veterinary Medicine, True Blue, St. George's, Grenada, West Indies.

E-mail: taire@sgu.edu; Fax: +4734441478

\begin{abstract}
The cellular composition of the testicular capsule, seminiferous peritubular tissue, the epithelia as well as periductal muscle cell layers of the excurrent ducts was studied, in sexually mature and active Masked Weaver (Ploceus velatus) birds of the passerine family, Ploceidae. Ultrastructure of the contractile cells in the testicular capsule, peritubular and periductal tissues showed that these cells were smooth muscles of typical morphological characteristics. Variability in the immunohistochemical co-expression of microfilaments and intermediate filaments in the different tissues was evident. Actin and desmin proteins were co-expressed
\end{abstract}


immunohistochemically in the testicular capsule and seminiferous peritubular smooth muscle layer. Actin was singly and very weakly expressed in the rete testis epithelium while cytokeratins and desmin were co-expressed in the epithelium of the excurrent ducts. The periductal muscle layer of all ducts of the epididymis, the ductus deferens as well as the seminal glomus, strongly co-expressed actin and desmin. Vimentin was absent in all cells and tissue types studied. There is clear evidence that the tissues of the male gonad and its excurrent ducts in the Masked Weaver, as has been reported for members of the Galloanserae and Ratitae, contain well-formed contractile tissues whose function would include the transportation of luminal through-flow from the testis into, and through, its excurrent ducts. The microtubule helix in the head and of the mid-piece, of elongating spermatids, as well as of the mature spermatozoa in the various excurrent ducts, including some spermatozoa in the seminal glomus, also co-expressed these three proteins.

Key words: passerine bird - microfilaments -- intermediate filaments - immunohistochemistry -- testis - excurrent ducts

\section{Introduction}

The mechanisms involved in, and controlling, contractile forces that propel testicular fluid and its sperm content from the testis into and through the excurrent ducts have received recent attention in mammals (Achtstätter et al., 1985; Banks et al., 2006; Davis et al., 1970; Dinges et al., 1991; Hargrove et al., 1977; Holstein and Weiss, 1967; Kasper and Stosiek, 1989; Maekawa et al., 1996; Miettinen et al., 1983; Ramaekers et al., 1985; Wakui et al., 1994; Wrobel et al., 1988; Steger and Wrobel, 1994). It has been established that hydrostatic pressure alone is not sufficient for the outflow of testicular fluid into and through the excurrent ducts, but that the testicular capsule and peritubular boundary tissue, comprising myoid or smooth muscle cells, 
play an important role in this regard (Banks et al., 2006; Hargrove et al., 1977; Middendorff et al., 2002). Smooth muscle cells have been indentified, ultrastructurally, immunohistochemically and pharmacologically in both the testicular capsule and peritubular boundary tissue of mammals (Banks et al., 2006; Davis and Langford, 1970; Maekawa et al., 1991, 1996; Schlatt et al., 1993; Virtanen et al., 1986). Similarly, smooth muscle cell layers have been demonstrated in the periductal tissue in the rete testis, tubulus rectus, and ductus epididymidis of mammals (Dinges et al., 1991 Kasper and Stosiek, 1989; Wakui et al., 1994).

Recent reports also have demonstrated the presence of various contractile cytoskeletal proteins (e.g. actin, cytokeratins, desmin and vimentin) in both epithelial and periductal tissue smooth muscle cells of the excurrent ducts of the testis in mammals (Achstätter et al., 1985; Ramaekers et al., 1985; Dinges, et al., 1991; Kasper and Stosiek, 1989; Palacios et al., 1993; Wakui et al., 1994). There are only a few reports on the contractile proteins in the testis and its complex excurrent duct system in birds (Aire, 1997; Aire and Ozegbe, 2007; Ozegbe et al., 2008, 2010; Maretta and Marettova, 2004; Rothwell and Tingari, 1973; van Nassauw et al., 1993). Actin microfilaments (MF) as well as desmin, cytokeratin and vimentin intermediate filaments (IFs) have been immunodemonstrated in both the testis and its excurrent ducts in members of the Galloanserae and Ratitiae (Maretta and Marettova, 2004, Aire and Ozegbe, 2007, Ozegbe et al., 2008, 2010).

The present report, on the occurrence and disposition of microfilaments and intermediate filaments in the cytoskeleton of cells in both the testis and excurrent ducts (including spermatids and spermatozoa, respectively), as well as the seminal glomus, which is a characteristic and 
distinguishing feature of passerine birds, seeks to complement the few, previous reports in birds (Aire and Ozegbe, 2007, Ozegbe et al., 2008, 2010). The germ cells, including early, round germ cells, elongated spermatids and mature spermatozoa within the testis and the excurrent ducts have been studied immunohistochemically, for the first time in birds, along with other parts of the ducts.

\section{Materials and methods}

Five sexually mature and active birds of the passerine species, Masked Weaver (Ploceus velatus) were studied, during their breeding season. The birds were terminally anaesthetized with an overdose of halothane, and quickly opened up for specimen sampling for histology and immunohistochemistry (3 birds) or intravascular perfusion for electron microscopy (two birds). For histology and immunohistochemistry, pieces of testicular, epididymal and ductus deferens tissues were obtained and fixed quickly in buffered 10\% formalin and Bouin's fluid. The tissues were further processed for light microscopy by standard and conventional histological methods, and embedded in paraffin wax. Paraffin sections of $5 \mu \mathrm{m}$ thickness were cut and mounted on the appropriate microscope slides, and thereafter, stained for light microscopy with haematoxylin and eosin. For immunohistochemistry, the sections were processed further, as detailed below.

For electron microscopy, the two birds were intravascularly perfused through the left ventricle, with 3\% glutaraldehyde buffered in sodium cacodylate buffer (Aire and Malmquist, 1979). The

fixed tissues were processed for transmission electron microscopy, using standard and conventional methods for plastic embedment. Semi- and ultra-thin sections were cut and stained appropriately for light and electron microscopy. 
For immunohistochemistry, selected formalin-fixed tissue sections, mounted on slides pre-coated with polylysine, were deparaffinized and treated with $3 \%$ hydrogen peroxide to inhibit endogenous peroxidase. After blocking the non-specific reaction, the sections were subsequently microwaved at $750 \mathrm{~W}$ for two cycles of seven minutes each in citrate buffer (pH 6). Thereafter, slides were allowed to cool at room temperature, for 20 minutes, before being rinsed in phosphate-buffered saline solution, containing bovine serum albumin ( $\mathrm{pH}$ 7.6), for 5 minutes. Subsequently, the sections were incubated with the specific primary antibody for 30 minutes, following the protocol of LSAB $+{ }^{\circledR}$ kit (DakoCytomation, Denmark). The antibodies used were smooth muscle actin (Monoclonal mouse anti-human smooth muscle actin; M085101; diluted 1: 50), cytokeratin (Monoclonal mouse anti-human cytokeratin; M082101; 1: 100), desmin (Monoclonal mouse anti desmin; A0611; 1: 300) and vimentin (Monoclonal mouse antivimentin; M072501; 1:100). After rinsing in PBS, each slide was incubated for 15 minutes in a link antibody (Biotinylated secondary antibody) and then peroxidase-labeled streptavidin. The antigen localization was visualised by incubation of the sections with either the 3,3diaminobenzidine $(\mathrm{DAB})$ of $\mathrm{LSAB}+{ }^{\circledR}$ kit or $\mathrm{VECTOR}^{\circledR} \mathrm{NovaRED}^{\mathrm{TM}}$ solutions. The sections were counterstained with haematoxylin.

\section{Results and observations}

For proper perspective, a brief description of the testicular capsule as well as the peritubular and periductal smooth muscle cells in the testis and excurrent ducts, respectively, is provided. Similarly, a brief introduction of the excurrent ducts of the testis is made. All excurrent ducts 
rested on a basal lamina that was surrounded by a layer of smooth muscles. The layer is thickest in the epididymal duct unit than in the rete testis and efferent ducts.

\section{Morphology of the testicular capsule, peritubular and periductal myoid cell layers}

The testicular capsule comprised the typical tissue layers of tunica serosa, tunica albuginea and tunica vasculosa. The testicular capsule was quite compact and displayed smooth muscle cells that ran parallel to one another, and a few, scattered fibroblasts that were interspersed between the smooth muscle cells. The peritubular myoid layer was up to five cell layers thick, and compact. The periductal muscle layer also comprised several layers of smooth muscle cells (Plate 1, Fig. 2), with one or two layers of fibroblasts intervening between the basal lamina and the smooth muscle layer. Ultrastructurally, the smooth muscle cells in the testicular capsule, peritubular and periductular muscle layers were similar in structure (Plate 1, Fig. 2). The smooth muscle cells were elongated and ran circularly, around the basal lamina. They exhibited elongated, generally euchromatic nuclei that had a few aggregations of heterochromatin attaching to the inner nuclear membrane. The central, organelle space contained mitochondria, a few, short profiles of rough endoplasmic reticulum and abundant free, and a few rosettes of, ribosomes. Microfilaments ran longitudinally along the long axis of the cell, and some radiated from the nuclear membrane toward, and attaching to, the cell membrane. Numerous cytoplasmic densities were also seen in the cytoplasm or attached to the cell membrane (Plate 1, Fig. 2).

\section{General organization and structure of the excurrent ducts}

The rete testis forms cavernous spaces within the peri-epididymal area of the testicular capsule and in its immediate region in the epididymis itself (Plate 1, Fig. 3; Plate 5, Fig. 1). The 
epithelium of cuboidal to low columnar comprise epithelial cells with large nuclei and sparse, diverse organelles (Plate 1, Fig. 3). The epithelium rests on a moderately thick muscle layer (Plate 5, Fig. 1).

The efferent ducts comprise proximal (PED) and distal (DED) segments. The PED (Plate 1, Fig. 4; Plates 5 and 6) has an irregular profile, occupies a greater proportion of the surface area of the epididymis than the DED, which has a regular profile. Both segments of the efferent duct unit (Aire, 2007) are lined by an epithelium containing both ciliated (C) and non-ciliated (NC) cells (Plate 1, Figs. 4 and 5), the latter exhibiting dense bodies in the supranuclear region of the cell, and being more numerous in the PED than in the DED. The periductal muscle layer is thicker in the efferent ducts than in the rete testis (Plate 6, Fig. 1; Plate 7, Fig. 1).

The epididymal duct unit (see Aire, 2007) comprises the connecting duct (CD), epididymal duct (ED), ductus deferens (DD) and seminal glomus (SG). All ductal segments are lined by the same type of columnar epithelium, containing only one non-ciliated cell type (NC type III; see Aire, 2007), whose apical surface bears short, regularly cylindrical microvilli (Plate 1, Fig. 6). The oval nucleus is located basally, and is euchromatic. The supranuclear region of the cell contains moderately abundant endoplasmic reticulum, well developed Golgi complex and numerous, relatively large, mitochondria. The periductal smooth muscle layer is thick, and the muscles are well defined (Plate 5, Figs. 1 and3; Plate 6, Fig. 2). 


\section{Spermatids and spermatozoa}

The mature spermatid or spermatozoon displays a helical profile due to the spiralling of bundles of microtubules and the single, long, strand of mitochondrion (Plate 2, Figs. 1, 5). The microtubular helix extends from the junction between the sinuous acrosome and nucleus, but the mitochondrial helix begins just caudal to the centriolar adjunct, and is responsible for the extremely long and equally sinuous mid-piece of the cell (Plate 2, Figs. 1 and 3). Both helices develop and become prominent during the elongation phase of spermiogenesis. The microtubular helix occupies an appreciable proportion of the surface area of the elongating spermatid, and along with the circular manchette, provides a considerable amount of microfilaments and intermediate filaments, especially in the nuclear region of the cell (Plate 2, Figs. 2, 3, 4, 5).

\section{Immunohistochemistry}

\section{Testis}

\section{Actin microfilaments}

Strongly actin-positive bundles of smooth muscle cells alternated with actin-negative parts or bundles of muscles in the testicular capsule (Plate 3, Fig. 2). The serosa was distinctly negative. The peritubular muscle cell layer surrounding seminiferous tubules was strongly positive (Plate 3, Fig. 1). Elongating and fully elongated spermatids displayed strong actin reaction in the head region, but weak reaction in the mid-piece. Sertoli cell cytoplasm was weakly- or moderatelypositive to actin (Plate 3, Figs. 1 and 3). 


\section{Cytokeratin intermediate filaments}

Neither the testicular capsule nor the peritubular muscle cell layer was immunoreactive for cytokeratin (Plate 4, Fig. 1). The heads of elongating spermatids were strongly positive, while those of the fully elongated, differentiated spermatids were moderately to strongly positive to cytokeratins (Plate 4, Figs. 1, 2 and 3). The mid-piece of the elongated spermatid was moderately immunoreactive. The Sertoli cell cytoplasm was moderately immunoreactive to cytokeratins (Plate 4, Fig. 1).

\section{$\underline{\text { Desmin }}$}

The testicular capsule exhibited scattered strands or alternating bundles of cells that were moderately to strongly immunoreactive for desmin (Plate 5, Fig. 1). The serosa and subserosal region of the capsule were strongly positive. The peritubular myoid cell layer was moderately to strongly immunoreactive to desmin (Plate 5, Fig. 1). The spermatocytes and round spermatids in the seminiferous epithelium were negatively immunoreactive, but the Sertoli cell cytoplasm was moderately positive to desmin (Plate 5, Fig. 3). The heads of the elongating spermatids were strongly immunostained, while the mid-pieces were moderately desmin-positive (Plate 5, Figs. 1, 2 and 3$)$.

\section{Vimentin}

All tissues and cells of the testis were immunonegative for vimentin. 


\section{Excurrent ducts of the testis}

$\underline{\text { Actin }}$

The periductal smooth muscle cell layer of all ducts was strongly stained for actin (Plate 6, Figs. 1 and 3). The epithelia of the various ducts of the epididymis as well as that of the ductus deferens were negative. However, the epithelium of the duct of the seminal glomus was very weakly positive or negative (Plate 6, Fig. 3), but the thick periductal muscle layer was strongly immunostained (Plate 6, Fig. 3). The interductal tissue was negative or very weakly positive. The microtubule bundles of the head and the fibrous components of the mid-piece of the spermatozoa, in the various ducts, from the rete testis to the ductus deferens, were moderately positive to actin (Plate 6, Fig. 2).

\section{Cytokeratin}

In the seminal glomus, the epithelium of the duct was very weakly positive to cytokeratin, while the periductal smooth muscle layer was moderately positive (Plate 7, Fig. 3). All other excurrent duct epithelium and smooth muscle layer were negative. The microtubule bundle and other fibrous elements of the spermatozoa in the excurrent ducts, from the rete testis to the ductus deferens, were moderately immunoreactive to cytokeratin (Plate 7, Fig. 4).

\section{$\underline{\text { Desmin }}$}

The apical part of the epithelium of the rete testis was only very slightly positive, and in both segments (PED and DED) of the efferent ducts, desmin was moderately immunostained in the apical part of the non-ciliated cells of the epithelium (Plate 7. Fig.1). The periductal smooth muscle layer was strongly positive, while the interductal tissue was weakly stained (Plate 7, Fig.1). The apical part of the epithelium of the duct of the seminal glomus, as for other segments 
of the epididymal duct unit, was very weakly immunostained, but the thick periductal smooth muscle cell layer was strongly positive (Plate 7, Fig. 2). The interductal tissue was only weakly positive. The microtubule helix of the head and tail of spermatozoa in the ducts, down to the ductus deferens, were weakly immunonegative to desmin (Plate 7, Fig. 4).

Vimentin

All cells and tissues of both the testis and excurrent ducts were immunonegative to vimentin.

\section{Discussion}

The testicular capsule of the Masked weaver, as has been described for members of the Galloanserae, is thin but relatively thick in the Ratitae (Aire and Ozegbe, 2007; Ozegbe et al., 2008). While the smooth muscle cells in the testicular capsule were generally regular and nonbranching, as in the Galloanserae, those of the ratites branched rather elaborately, with sheets of cytoplasm meandering between and enclosing bundles of collagen fibres. The ultrastructure of the smooth muscle cells is similar in all Orders of birds studied so far (Aire and Ozegbe, 2007; Ozegbe et al., 2008; Rothwell and Tingari, 1973). There is no remarkable variability in ultrastructure of the smooth muscle cell in either the testicular capsule, peritubular or periductal tissues. As in mammals (Lesson and Forman 1981; Langford and Heller 1973; Holstein and Weiss 1967; Banks et al., 2006) and other birds (Aire and Ozegbe, 2007; Ozegbe et al., 2008), the testicular capsule, peritubular and periductal tissues contain smooth muscle cells that are most probably responsible for transporting testicular fluid from the testis into and through its excurrent ducts. 
The excurrent ducts of the testis of the Masked weaver are generally similar to those described for a number of non-passerine birds (Tingari, 1971, 1972; Hess et al., 1976; Budras and Sauer, 1975; Aire, 1979; Aire et al., 1979; Aire and Soley, 2002, 2003). The notable exception is the presence of the seminal glomus in the passerine bird. This portion of the duct unit appears as a ball of highly convoluted duct at the terminal part of the ductus deferens. In this preliminary study, the epididymal duct unit is lined by non-ciliated cells. Ciliated cells were not present, and the general fine structure of the non-ciliated cell appears similar to that described for other birds studied. A comprehensive study of the excurrent ducts of the testis of several passerine birds is necessary in order to resolve current controversies regarding their duct types, epithelial composition, structure and function in this very large order of birds.

In the present report, both actin MF and desmin IF were present in the testicular capsule of the Masked Weaver, as was, also, demonstrated in the same tissue in members of the Galloanserae and Ratitae (Aire and Ozegbe, 2007, Ozegbe et al., 2008). Co-expression of actin and desmin in the muscles of the testicular capsule seems to be common to all three Orders of birds. Whereas actin was absent in the serosal and subserosal areas of the testicular capsule, desmin was strongly positive in these layers, which suggests that the serosal region contains different filamentous proteins. Vimentin was absent in the testicular capsule of the Masked Weaver (present study) and domestic fowl, turkey and duck but immunoexpressed, albeit, weakly in the quail (Aire and Ozegbe, 2007) and very strongly in the emu (Ozegbe et al., 2008). In ratites, on the other hand, the peritubular myoid cells co-expressed actin, desmin and vimentin in the emu, but in the ostrich, only actin was strongly immunoexpressed, while desmin, at best, was very weak, and vimentin was absent. Cytokeratins have not been immunodemonstrated in the testicular capsule 
of any of the birds that have been studied, to-date. The early and late series of elongating spermatids, similar to steps 3 to 6 (Góes and Dolder, 2002) as well as spermatozoa, in the more proximal segments of the excurrent ducts, demonstrated strong co-expression of actin, desmin, and cytokeratin immunorection in their microtubule helix. Similarly, in Sertoli cells, actin, desmin and cytokeratin contractile elements were also co-expressed. The microtubule helix of the head of the mature spermatozoon in the various excurrent ducts, including a few in the seminal glomus, also co-expressed these three proteins. The absence of microfilaments and intermediate filaments in most of the spermatozoa in the seminal glomus is probably a reflection of their loss of the microtubule helix in this part of the epididymal duct unit. It is for the same reason that elongating spermatids as well as spermatozoa in both the testis and its excurrent ducts do not express any of the microfilaments and intermediate filaments in members of the Galloanserae (Aire and Ozegbe, 2008) and Ratitae (Ozegbe et al., 2010). In their study, Ferreira et al. (2006) observed that actin microfilament was detected immunocytochemically only in the perforatorium and in the subacrosomal area of the sperm of the lizard, Tropidurus itambere. The role of the microtubule helix in the passerine spermatid and, possibly, spermatozoon, is, at best, conjectural. There is no agreement on their probable function in the developing and evolving, elongating spermatid (Fawcett et al., 1971; Kondo et al., 1988).

A similar pattern of variability in, and co-expression of, cytoskeletal protein immunoexpression, as seen in the testicular capsule, was observed in the excurrent ducts of birds. Thus, although actin and vimentin were strongly immunoreactive in the rete testis (RT) epithelium of the majority of the birds of the Galloanserae monophyly studied, yet desmin and cytokeratin were absent in the RT epithelium of this monophyly (Aire and Ozegbe, 2007). Only vimentin was 
present, and very strongly, in the epithelium of the RT of the emu, but not ostrich (Ozegbe et al., 2008). While desmin was demonstrated in the epithelium of the excurrent ducts in the passerine (this report), the emu displayed actin, cytokeratin, desmin and vimentin in the efferent duct epithelium, as against only cytokeratin in the ostrich (Ozegbe et al., 2008). In mammals, cytokeratins and vimentin were co-expressed in the efferent duct epithelium of the human (Dinges et al., 1991; Kasper and Stosiek, 1989), but only cytokeratins in the epithelium of the efferent ducts of the dog (Wakui et al., 1994). It is interesting that the epididymal duct unit did not immunostain for any of the microfilaments and intermediate filaments, to any appreciable degree in the Masked Weaver. Cytokeratins and vimentin were present, in a heterogeneous manner, in the epithelium of the epididymal duct in the dog (Wakui et al., 1994) and human (Kasper and Stosiek, 1989).

The smooth muscle cell layer investing the various excurrent ducts co-expressed actin and desmin strongly but cytokeratins were only moderately demonstrated in the Masked Weaver. This was similar to the situation in the ratites (Ozegbe et al., 2008), and the Galloanserae monophyly (Aire and Ozegbe, 2007). The smooth muscle cell layer investing the complexly coiled duct of the seminal glomus is very thick, and obviously has a considerable contractile force, needed to transport spermatozoa out of the excurrent ducts. The precise function of the seminal glomus of passerine birds is not clearly understood, but it is probably a transient, overnight storage site for spermatozoa (Birkhead et al., 1994) at temperatures that are lower than core body temperature (Wolfson, 1954). 
From the foregoing, there is considerable variability in the immunoexpression of microfilaments and intermediate filaments not only between species, but also, and to a larger extent, between Orders and Families of animals (Banks et al., 2006; Dinges et al., 1991; Palacios et al., 1991; Wakui et al., 1994). These differences have been attributed to possible species-specific variations in the transformational processes of fibroblasts into smooth muscle cells in the myoid cell population (Bustos-Obregon and Courot, 1974; Leeson and Forman, 1981; Wrobel et al., 1979), and, perhaps, to the fact that smooth muscle cells are not single entities, because they are capable of expressing differentially, not only synthetic but also contractile activities, at both ends of the spectrum (Banks et al., 2006).

The present report complements previous morphological and immunohistochemical studies in other Orders and Families of birds, Galloanserae and Ratitae (Aire and Ozegbe, 2007; Maretta and Marettova, 2004; Ozegbe et al., 2008, 2010; van Nassauw et al., 1993), with regard to contractile elements in the testis and its excurrent ducts. There is a great deal of variability in the immunoexpression of different microfilament and intermediate filament systems between this passerine bird and other birds studied (Aire and Ozegbe, 2007; Maretta and Marettova, 2004; Ozegbe et al., 2008, 2010; van Nassauw et al., 1993), and between birds and mammals, as there are between mammals (Dinges et al., 1991; Kasper and Stosiek, 1989; Palacios et al., 1991; Wakui et al., 1994). This variability is not understood, and would require further and more precise studies in order to attain clarity and understanding because the contractile capacity of the periductal smooth muscle cells of the various ducts of the excurrent ducts, obviously constitutes the major motive force for the transportation of spermatozoa through and out of the excurrent 
ducts of birds, as also observed in mammals (Banks et al., 2006; Dinges et al., 1991; Kasper and Stosiek, 1989; Palacios et al., 1991; Wakui et al., 1994).

\section{References}

Achtstätter, T., Moll, R., Moore, B., Eranke, W. W., 1985. Cytokeratin polypeptide pattern of different epithelia of the human male urogenital tract: immunofluorescence and gelelectrophoretic studies. Histochem. Cytochem. 33, 415-426.

Aire, T. A., 1997. The structure of the interstitial tissue of the active and resting avian testis. Onderstepoort J. Vet. Res. 64, 291-299.

Aire, T. A., 2007. Anatomy of the testis and male reproductive tract. In Reproductive Biology and Phylogeny of Birds. Jamieson, B. G. M. (Ed.), New Hampshire, USA, Plymouth, UK: Science Publishers, Inc., Vol. A, pp 37-113.

Aire, T. A., Ayeni, J. S., Olowookorun, M. O. 1979. The structure of the excurrent ducts of the testis of the guinea-fowl (Numida meleagris). J. Anat. 129, 633-643.

Aire, T. A., Malmqvist, M., 1979. Macrophages in the excurrent ducts of the testes of normal domestic fowl (Gallus domesticus). Zentralblatt für Veterinär Medicin C. Anat. Histol. Embryol. $8,172-176$.

Aire, T. A., Ozegbe, P. C., 2007. The testicular capsule and peritubular tissue of birds: morphology, histology, ultrastructure and immunohistochemistry. J. Anat. 210, 731-740. 
Aire, T. A., Ozegbe, P. C., 2008. Immunohistochemistry of the cytoskeleton in the excurrent ducts of the testis in birds of the Galloanserae monophyly. Cell Tiss. Res. 333, 311-321.

Aire, T. A., Soley, J. T. 2000. The surface features of the epithelial lining of the epididymis of the ostrich. Anat. Histol. Embryol. 29. 119-126.

Aire, T. A., Soley, J. T. 2003. The morphological features of the rete testis of the ostrich (Struthio camelus). Anat. Embryol. 207, 355-361.

Banks, F. C. L., Knight, G. E., Calvert, R. C., Turmaine, M., Thompson, C. S., Mikhalidis, D. P., Morgan, R. J., Burnstock, G., 2006. Smooth muscle and purinergic contraction of the human, rabbit, rat, and mouse testicular capsule. Biol. Reprod. 74, 473-480.

Birkhead, T. R., Verga, J. P., Molleer, A. P., 1994. Male sperm reserves and copulation behaviour in the house sparrow, Passer domesticus. Proceed. Roy. Soc. Lond. B. 256, 247-251.

Budras, K.-D., Sauer, T. 1975. Morphology of the epididymis of the cock (Gallus domesticus) and its effect upon the steroid sex hormone synthesis. II. Steroid sex hormone synthesis in the tubuli epididymis and the transformation of the ductuli aberrantes into hormone producing noduli epididymidis in the capsule of the adrenal gland of the capon. Anat. Embryol. 148, 197-213.

Bustos-Obregon, E., Courot, M., 1974. Ultrastructure of the lamina propria in the ovine seminiferous tubule. Development and some endocrine considerations. Cell Tiss. Res. 150, 481492. 
Davis, J. R., Langford, G. A., 1970. Pharmacological studies of the testicular capsule in relation to sperm transport. Rosenberg, E., Paulsen, C. A., (eds.). In: The Human Testis, Plenum, New York, pp. 495-514.

Davis, J. R., Langford, G. A., Kirby, P. J., 1970. The testicular capsule. In: Johnson, A. D., Gomes, R., Vandemark, N. L., (Eds.), The Testis. Development, Anatomy and Physiology. Academic Press, London, Vol. 1, pp 281 - 337.

Dinges, H. P., Zatloukal, K., Schmid, C., Mair, S., Wirnsbeger, G., 1991. Co-expression of cytokeratin and vimentin filaments in rete testis and epiddiymis. Virchows Archiv. A Path. Anat. Histopath. 418, 119-127.

Fawcett, D. W., Anderson, W. A., Phillips, D. M. 1971. Morphogenetic factors influencing the shape of the sperm head. Dev. Biol. 26, 220-251.

Ferreira, A., Mehanna, M., Dolder, H., 2006. Ultrastructural immunocytochemical evidence for actin in theacrosomal complex during spermiogenesis of the lizard Tropidurus itambere (Rodrigues, 1987) (Reptilia: Tropiduridae). Caryologia 59, 213-219, 2006

Góes, R. M., Dolder, H., 2002. Cytological steps during spermiogenesis in the house sparrow (Passer domesticus, Linnaeus). Tiss. Cell 34, 273-282.

Hargrove, J. L., MacIndoe, J. H., Ellis, L. C., 1977. Testicular contractile cells and sperm transport. Fertil. Steril. 28, 146-1157.

Hess, R. A., Thurston, R. J., Bieller, H. V. 1976. Ultrastructure of the epididymal region and ductus deferens of the turkey (Meleagris gallopavo). J. Anat. 122,241-252.

Hodges, R. D., 1974. The Histology of the Fowl. Academic Press, London. 
Holstein, A. F., Weiss, C., 1967. Über die Wirkung der glatten Muskulatur in der Tunica albuginea in Hoden des Kaninchens; Messungen des intersitiellen Druckes. Zeitschrift Gesamte Experiment. Med. Einschl. Experiment. Chirurg. 142, 334-337.

Kasper, M., Stosiek, P., 1989. Immunohistochemical investigation of different cytokeratins and vimentin in the human epididymis from the fetal period up to adulthood. Cell Tiss. Res. 257, 661-664.

Kondo, T., Hasegawa, K., Uchida, T. A. 1988. Formation of the microtubule bundle and helical shaping of the spermatid in the Common Finch, Lonchura striata var. domestica. J. Ultrastruct. Mol. Res. 98, 158-168.

Leeson, C. R., Forman, D. E., 1981. Postnatal development and differentiation of contractile cells within the rabbit testis. J. Anat. 132, 491-511.

Maekawa, M., Kamimura, K., Nagano, T., 1996. Peritubular myoid cells in the testis: their structure and function. Archs. Histol. Cytol. 59, 1-13.

Maekawa, M., Nagano, T., Kamimura, T., Ishikawa, H., Dezawa, M., 1991. Distribution of actin-filament bundles in myoid cells, Sertoli cells, and tunica albuginea of rat and mouse testes. Cell Tiss. Res. 266, 295-300.

Maretta, M., Marettova, E., 2004 Immunohistochemical demonstration of myoid cells in the testis and its excurent ducts in the domestic fowl. Brit. Poult. Sci. 45, 585-589.

Miettinen, M., Virtanen, I., Talerman, A., 1985. Intermediate filament proteins in human testis and testicular germ-cell tumors. Am. J. Pathol. 120, 402-410.

Ozegbe, P. C., Aire, T. A., Madekurozwa, M.-C., Soley, J. T., 2008. Morphological and immunohistochemical study of the testicular capsule and peritubular tissue of the emu (Dromaius novaehollandiae) and ostrich (Struthio camelus). Cell Tiss. Res. 332, 151-158. 
Ozegbe, P. C., Kimaro, W., Madekurozwa, M.-C., Soley, J. T., Aire, T. A., 2010. The Excurrent Ducts of the Testis of the Emu (Dromaius novaehollandiae) and Ostrich (Struthio camelus): Microstereology of the Epididymis and Immunohistochemistry of its Cytoskeletal Systems. Anat. Histol. Embryol. 39, 7-16.

Palacios, J., Regadera, J., Paniagua, R., Gamallo, C., Nistal, M, 1993. Immunohistochemistry of the human ductus epididymis. Anat. Rec. 235, 560-566.

Ramaekers, F. C. S., Feitz, W., Moeske, O., Schaart, G., Herman, C., Debruyne, F., Vooijes, G. P., 1985. Antibodies to cytokeratin and vimentin in testicular tumour diagnosis. Virchows Arch. A Pathol. Anat. 408, 127-142.

Rothwell, B., Tingari, M. D., 1973. The ultrastructure of the boundary tissue of the seminiferous tubule in the testis of the domestic fowl (Gallus domesticus). J. Anat. 114, 321-328.

Schlatt, S., Weinbauer, G. F., Arslan, M., Nieschlag, E., 1993. Appearance of $\alpha$-smooth muscle actin in peritubular cells of monkey testes is induced by androgens, modulated by folliclestimulating hormone, and maintained after hormonal withdrawal. J. Androl. 14, 340-350.

Steger, K., Wrobel, K.-H., 1994. Immunohistochemical demonstration of cytoskeletal proteins on the ovine testis during postnatal development. Anat. Embryol. 189, 521-530.

Tingari, M. D. 1971. On the structure of the epididymal region and ductus deferens of the domestic fowl (Gallus domesticus). J. Anat. 109, 423-435.

Tingari, M. D. 1972. The fine structure of the epithelial lining of the excurrent duct system of the testis of the domestic fowl (Gallus domesticus). Quart. J. Expt. Physiol. 57, 271-295. 
Van Nassauw, L., Harrison, F., Callebaut, M., 1993. Smooth muscle cells in the peritubular tissue of the quail testis. Eur. J. Morphol. 31, 60-64.

Virtanen, I., Kalljoki, M., Närvänen, O., Paranko, L. E., Miettinen, M., Lehto, V-P., 1986. Peritubular myoid cells of human and rat testis are smooth muscle cells that contain desmin-type intermediate filaments. Anat. Rec. 215, 10-20.

Wakui, S., Furusato, M., Ushigome, S., Kano, Y., 1994. Co-expression of different cytokeratins, vimentin and desmin in the rete testis and epididymis in the dog. J. Anat. 184, 147-151.

Wolfson, A., 1954. Sperm storage at lower than body temperature outside the body cavity in some passerine birds. Science 120: 68-71.

Wrobel, K.-H., Dostal, S., Schimmer, M., 1988. Postnatal development of the tubular lamina propria and the intertubular tissue in the bovine testis. Cell Tiss. Res. 252, 639-653.

Wrobel, K.-H., Mademann, R., Sinowatz, F., 1979. The lamina propria of the bovine seminiferous tubule. Cell Tiss. Res. 202, 357-377. 


\section{LEGENDS}

PLATE 1: This plate contains, mainly, electron micrographs of the testicular capsule and excurrent ducts of the testis, that provide a panoramic view of the duct types in the epididymis of the Masked weaver bird. Fig. 1 shows the peritubular myoid cells (arrowheads), the seminiferous epithelium (SEM) and Leydig cell (LC) in the interstitium. Fig. 2 is a higher power view of several muscle cells ( 1 to 4 ) in a periductal muscle layer, displaying (inset) abundant microfilaments/intermediate filaments (arrowhead) and cytoplasmic densities (arrow). Fig. 3 shows the columnar epithelium of the rete testis. The organelle content is sparse, and the luminal surface bears very few, short, regular microvilli (arrow). Fig. 4 displays the epithelium of the proximal efferent duct (PED). Both ciliated (C) and non-ciliated (NC) cells are present. Numerous, long, regular microvilli (arrow) line the apical surface of the NC cell, while cilia (arrowhead) project from the luminal surface of the $\mathrm{C}$ cells. Note the numerous dense bodies (D) in the supranuclear region of the cytoplasm. Fig. 5 shows the epithelium of the distal efferent duct (DED), which is columnar and contains both $\mathrm{C}$ and $\mathrm{NC}$ cells, the former being more numerous than the NC cells whose cytoplasm does not contain dense bodies. unlike in the PED. Fig. 6 is a profile of the epithelium of the ductus deferens (DD) of the epididymal duct unit. The columnar epithelium contains only the non-ciliated type III cells as well as basal cells that are absent in the earlier duct units [rete testis and efferent ducts unit]. The luminal surfaces of the $\mathrm{NC}$ cells bear numerous, short, regular microvilli (arrowhead). Numerous, large mitochondria (star) and well developed Golgi complex (G) adorn the supranuclear region of the NC cell. 
PLATE 2: this plate provides a developmental perspective of the spermatids with a view to understanding immunoreactivity to microfilaments and intermediate filaments on the spermatid surface. Fig. 1 shows a bunch of nearly mature elongated spermatids displaying sinuous acrosome (Ac), nuclei (N) and tail (arrowhead). The microtubular helix (arrows) winds round both the nucleus and tail (arrows). Fig. 2 is a mid-phase elongating spermatid displaying well formed and conspicuous microtubule helix (arrows) around the nucleus and tail (Ax) segments of the spermatid. $\mathrm{Cad}=$ centriolar adjunct. Fig. 3 An elongating spermatid displays both helical components, i.e. microtubular (Arrows) and mitochondrial (arrowhead) helices, as well as the centriolar adjunct (Ac). Fig. 4 short profiles of spermatids at the final stages of nuclear condensation exhibiting large a microtubular helix (arrows). In such profiles, the microtubular reaction to antibodies is a little exaggerated. Fig. 5 shows short profiles of mature spermatids displaying a greater proportion of the microtubular helix than is normally so. $\mathrm{Ax}=$ axoneme; $\mathrm{Cad}$ $=$ centriolar adjunct.

PLATE 3: Actin reactivity was strongly present in the peritubular myoid cells of the testis (Fig. 1; arrowheads), as well as in alternating bundles in the testicular capsule (Fig. 2; star). The heads of elongating spermatids were similarly strongly positive to actin (Fig.1, arrows; Fig. 3, arrowheads) and the mid-pieces were moderately positive (Fig. 3; arrow). The cytoplasm of the Sertoli cells was weakly-to-moderately positive to actin (Fig. 1; squat arrows).

PLATE 4: Cytokeratins were not immunostained in either the testicular capsule or peritubular (Fig. 1; arrows) smooth muscle cells of the Masked weaver, but the heads (Fig. 1, 2 and 3: arrowheads) and mid-piece regions (Fig. 2, arrow) of elongating spermatids were strongly and 
moderately stained, respectively, for cytokeratin. Sertoli cell cytoplasm was moderately stained for this intermediate filament (star).

PLATE 5: In Fig. 1, desmin stains strongly in the testicular capsule (Tc), in a layered manner, as it was for actin. The peritubular myoid cell layer was strongly immunostained (arrow), and the heads of elongated spermatids (arrowheads) were also strongly stained (Figs. 1, 2 and 3). The mid-piece of spermatids was moderately stained (Fig. 2; arrow). The Sertoli cytoplasm was moderately stained for desmin (Fig. 3; arrow).

PLATE 6: In the epididymis of this bird, the periductal smooth muscle cell layer (arrows) was strongly positive for actin in all ducts, and very weakly or absent in cells of the interstitial tissue (T) (Fig. 1). The epithelium (arrowheads) of all ducts (Figs. 1, 3) was negative, except for that of the seminal glomus which was very weakly positive (Fig. 3; arrowhead). The microtubule bundles of the heads of spermatozoa in the earlier duct series was strongly actin-positive (Fig. 2; arrowheads), while the tails of the spermatozoa were only moderately stained (Fig. 3; white arrow). Star $=$ testicular capsule; $\mathrm{RT}=$ intracapsular rete testis duct.

PLATE 7: In Fig. 1, the apical region of the non-ciliated cells in the efferent ducts (PED), as well as that of the epididymal duct unit (Ed) was moderately positive for desmin activity (arrowheads). The testicular capsule (Tc) at the orchido-epididymal border displayed a few moderately positive strands of cells, unlike the capsule in other parts of the testis (vide Fig. 3, Tc). The periductal muscle cells were strongly positive for desmin (arrows), and the interstitial tissue (T) was only weakly positive. $\mathrm{S}=$ seminiferous epithelium. Fig. 2, the epithelium (E) of 
the ductus deferens, representing the epididymal duct unit, was negative to desmin, but the periductal muscle cell layer (star) was strongly positive. The microtubule bundles of the heads of spermatozoa (Fig.2: inset, arrowheads) in the lumen (Fig. 2; arrowhead) of the various ducts were moderately to strongly positive for desmin; the mid-piece of each spermatozoon was weakly-to-moderately positive.

In Fig. 3, the epithelium (Ep) of the ductus deferens was very weakly stained for cytokeratins, but the smooth muscle cell layer (My) of the duct was moderately positive to cytokeratins. In Fig. 4, the microtubule bundles of the heads (arrowheads) and mid-pieces (arrow) of spermatozoa in the lumen of the earlier duct series were strongly and moderately, stained, respectively, for cytokeratins. 


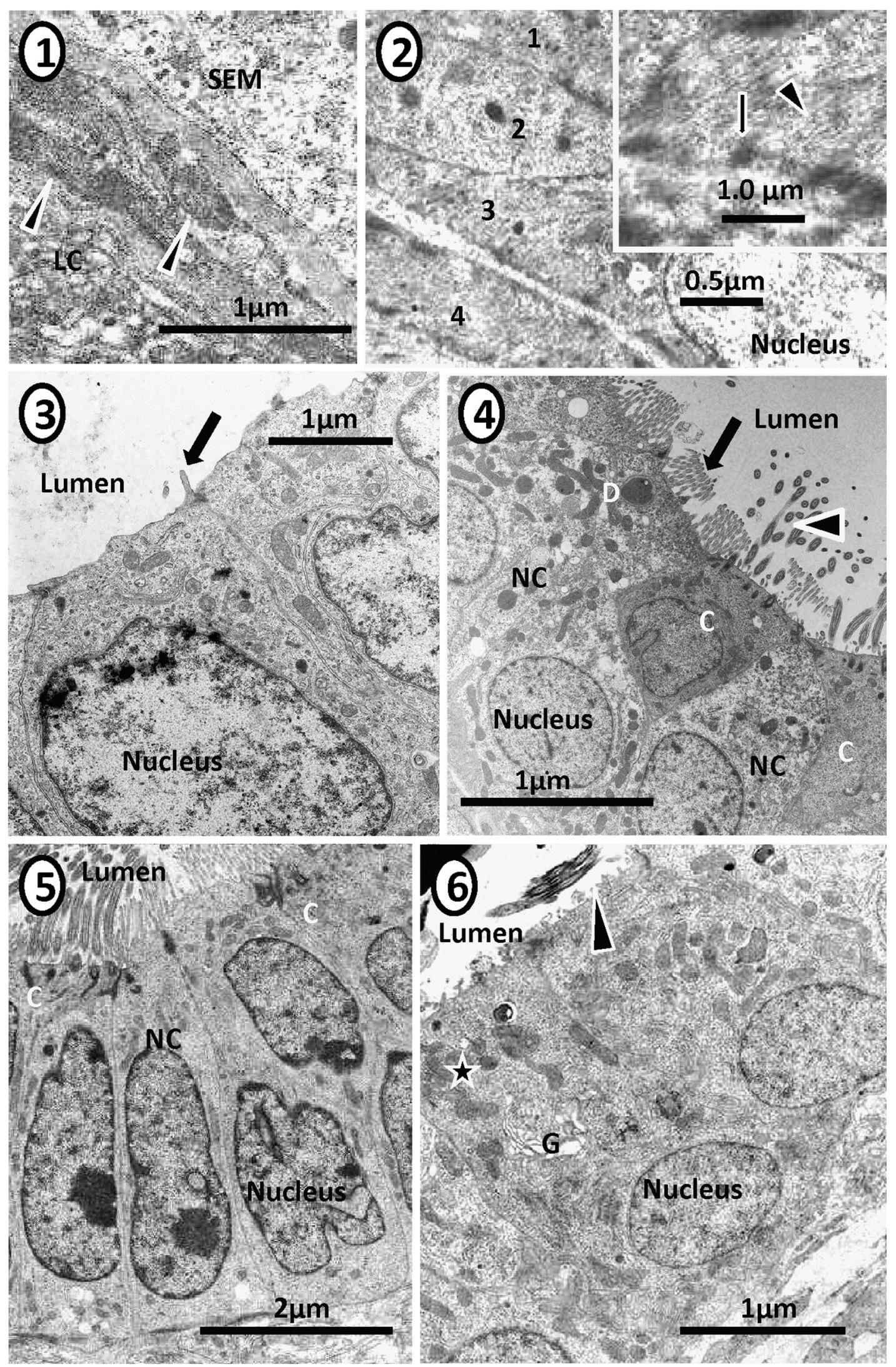

PLATE 1 

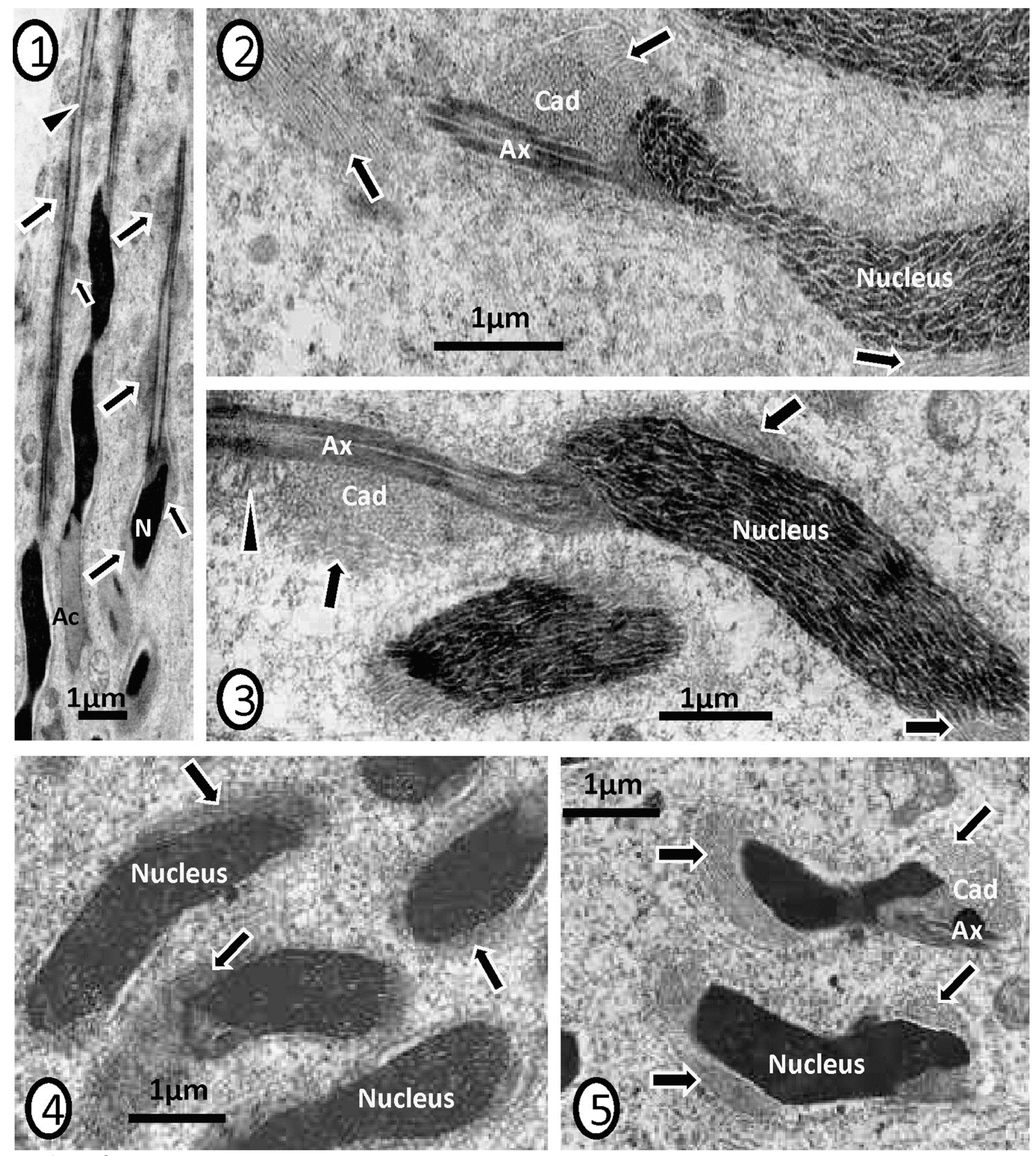

PLATE 2 


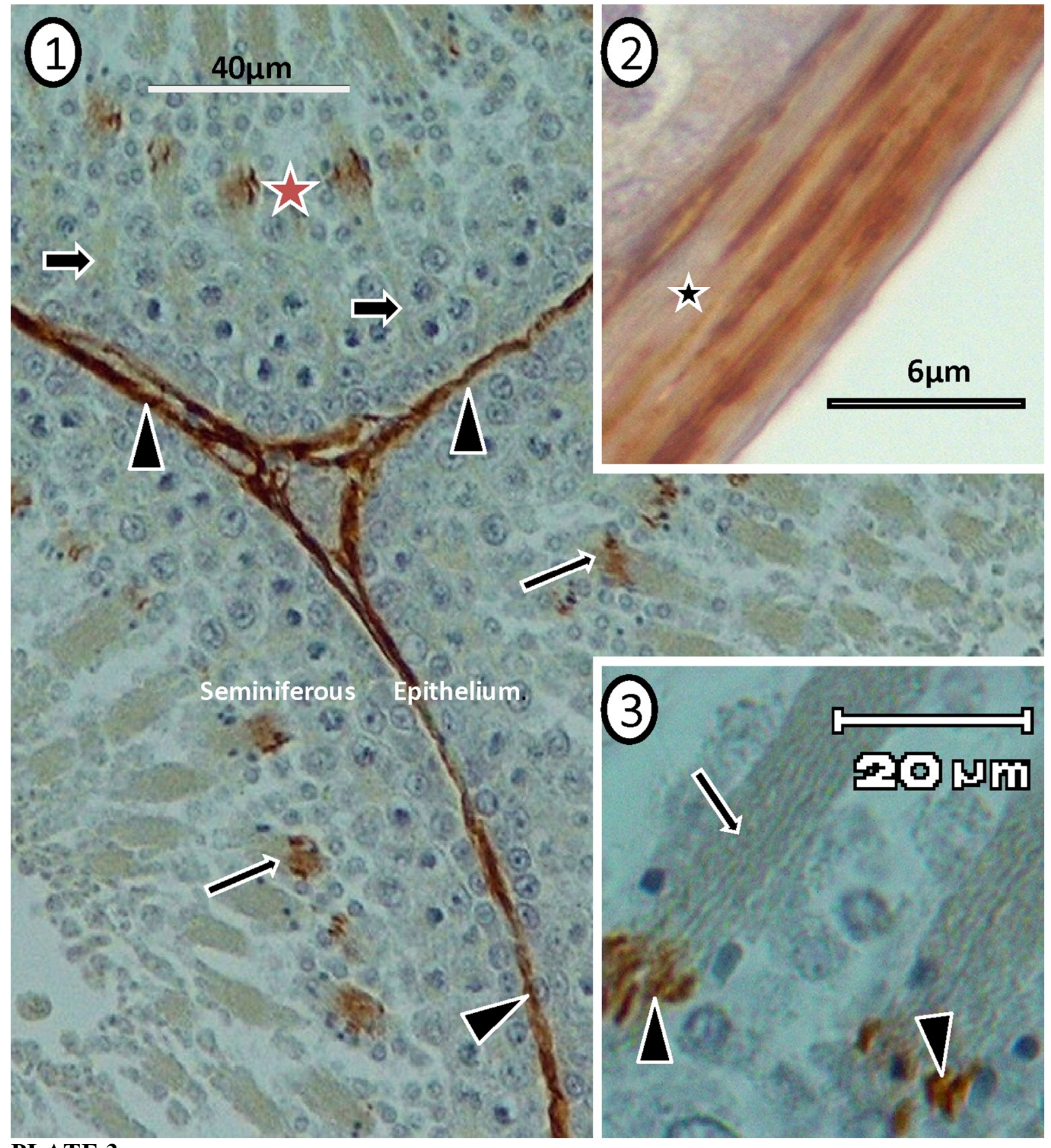

PLATE 3 

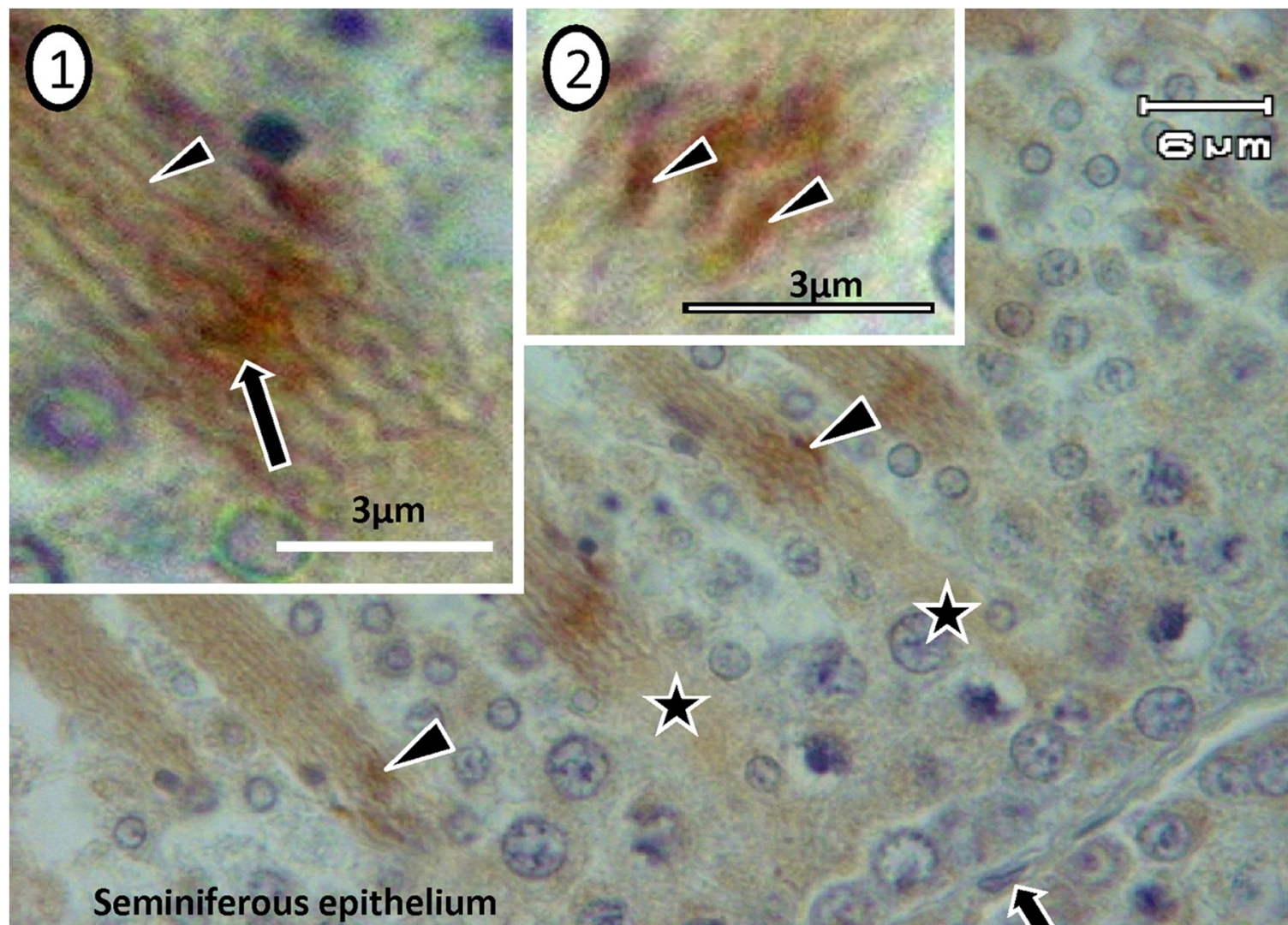

$\star$

$\star$

PLATE 4 


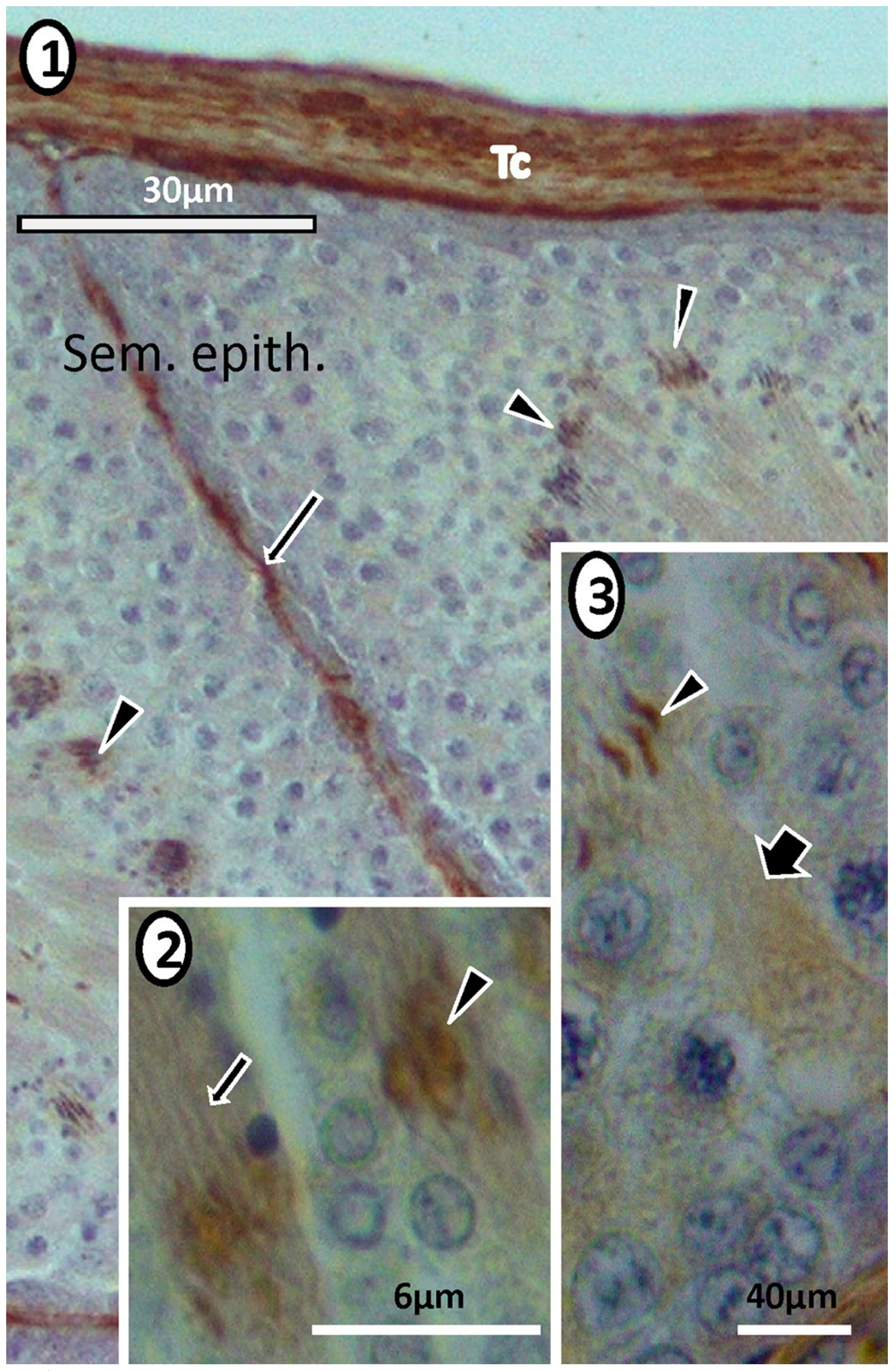

PLATE 5 


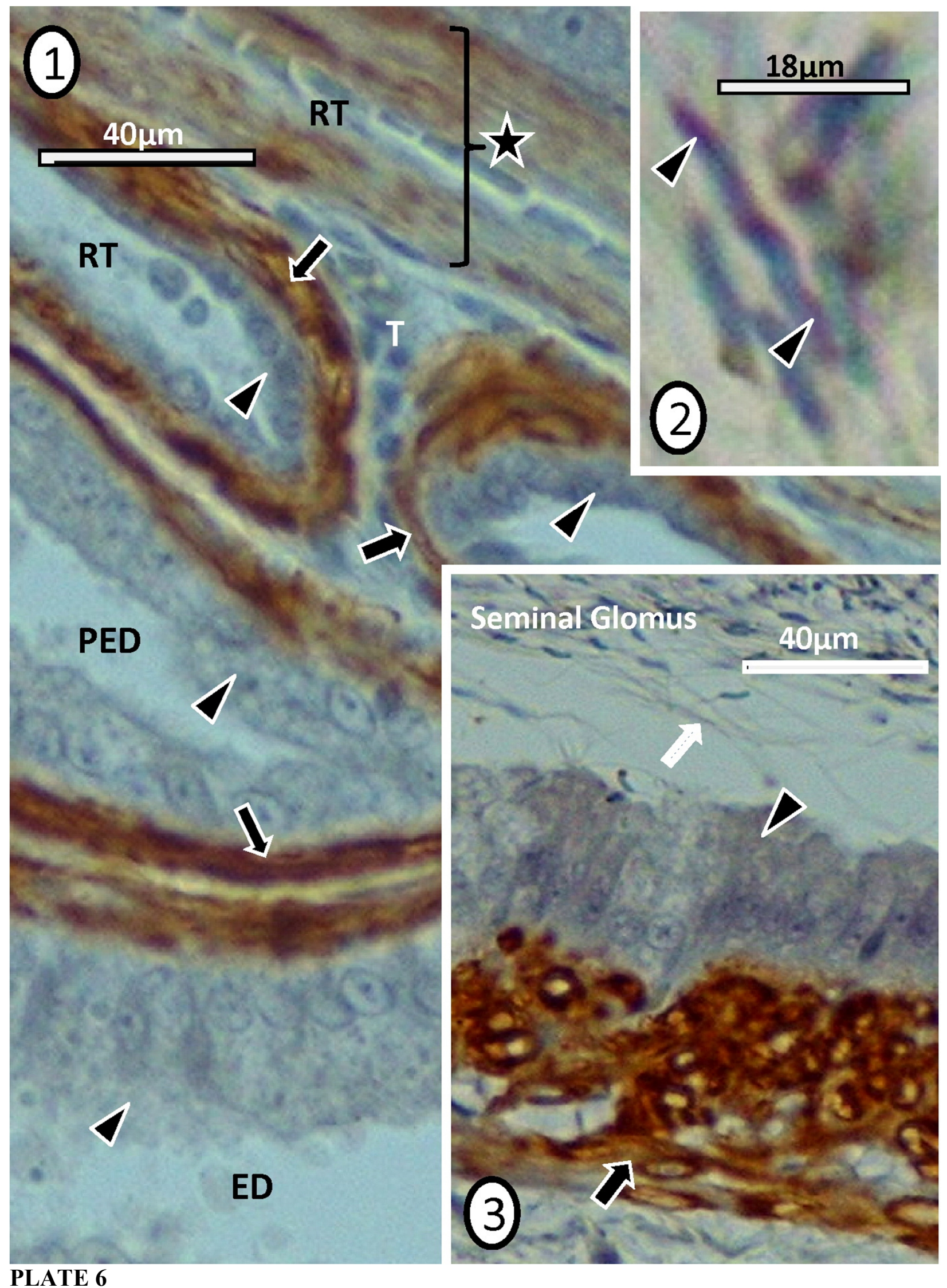




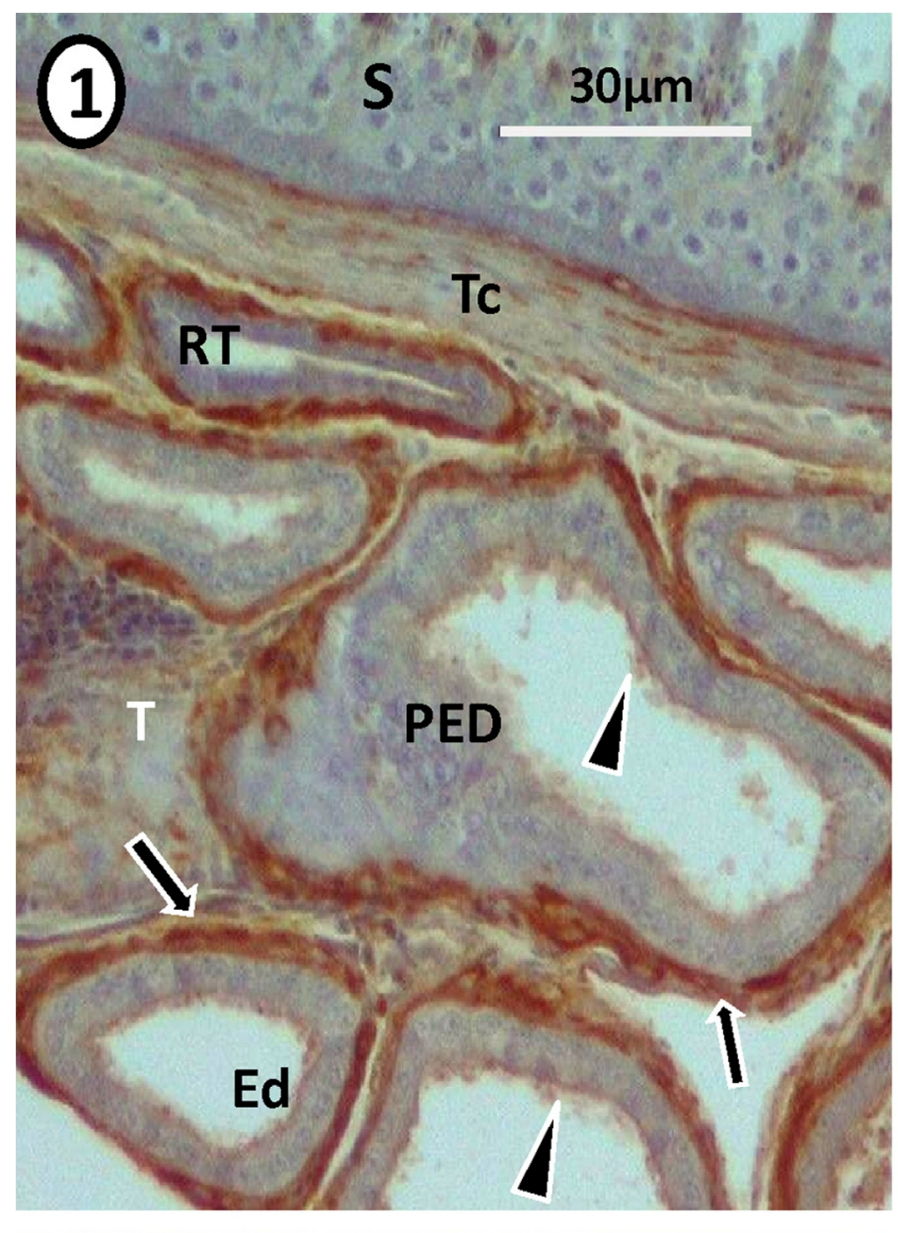

(3)

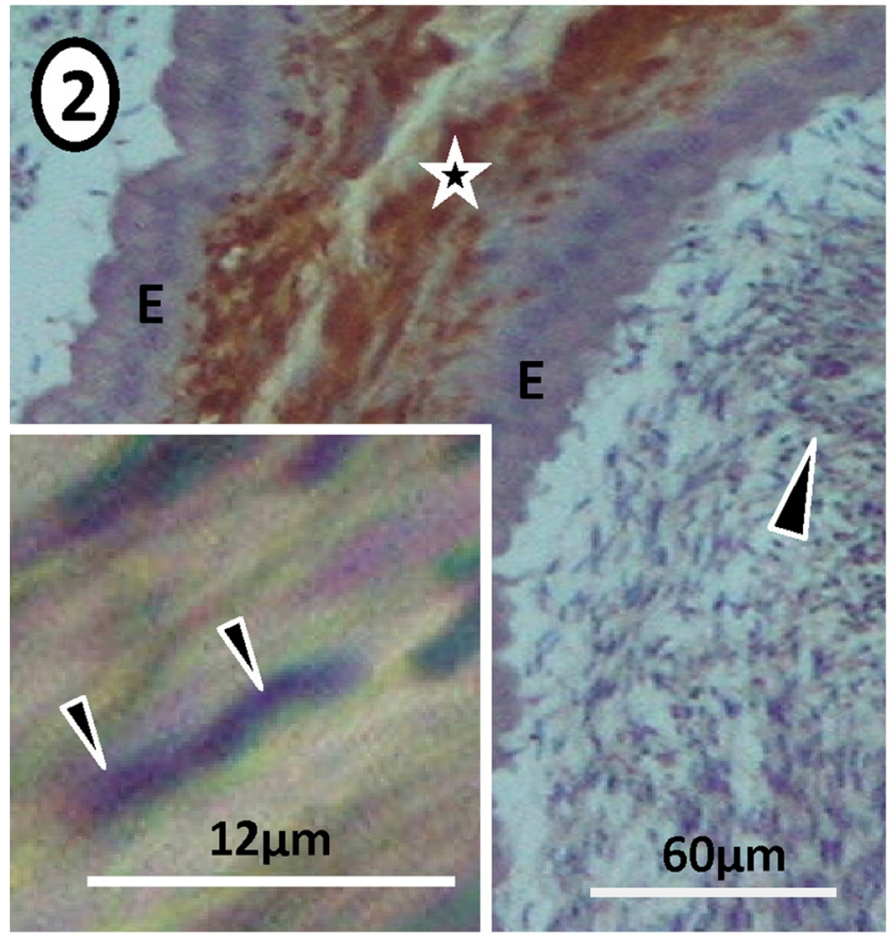

$12 \mu \mathrm{m}$
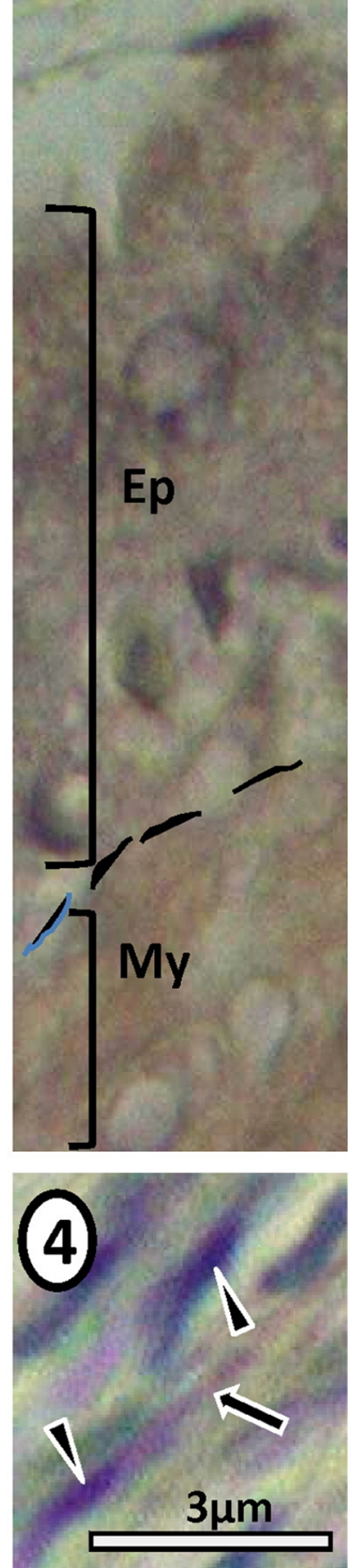

PLATE 7 
Table 1: Immunohistochemical co-expression of microfilaments and intermediate filaments in the

testis and its excurrent ducts of the Masked Weaver

\begin{tabular}{|c|c|c|c|c|c|c|c|c|}
\hline \multicolumn{3}{|c|}{ Testis } & \multicolumn{4}{|c|}{ Excurrent duct epithelium and sperm } & \multicolumn{2}{|c|}{$\begin{array}{l}\text { Peri- and inter-ductal tissue of } \\
\text { the epididymis }\end{array}$} \\
\hline Capsule & $\begin{array}{l}\text { Peritubular } \\
\text { tissue }\end{array}$ & $\begin{array}{l}\text { Spermatids and } \\
\text { Sertoli cells }\end{array}$ & $\begin{array}{l}\text { Rete } \\
\text { testis }\end{array}$ & $\begin{array}{l}\text { Efferent } \\
\text { ducts }\end{array}$ & $\begin{array}{l}\text { Epididymal } \\
\text { duct unit }\end{array}$ & Sperm & $\begin{array}{l}\text { Periductal muscle } \\
\text { tissue }\end{array}$ & $\begin{array}{l}\text { Interductal } \\
\text { tissue }\end{array}$ \\
\hline
\end{tabular}

${ }^{+} / 2=$ very weak reaction; $+=$ weak $++=$ moderate $+++=$ strong; $\mathbf{A}=$ actin; $\mathbf{D}=\operatorname{desmin} ; \mathbf{C}=$ cytokeratins; $\underline{\mathbf{S G}}=$ seminal glomus 